\title{
IMPLEMENTASI GOOGLE SUITE FOR EDUCATION UNTUK PENINGKATAN PROSES BELAJAR MENGAJAR DI ERA PANDEMI COVID 19 DI SMPN 2 SURAKARTA
}

\author{
Haryono Setiadi ${ }^{1}$, Dewi Wisnu Wardani ${ }^{2}$, Endar Suprih Widayat ${ }^{3}$, Maria Ulfa ${ }^{4}$ \\ ${ }^{1}$ U Program Studi Informatika Universitas Sebelas Maret \\ ${ }^{2}$ Program Studi Informatika Universitas Sebelas Maret \\ ${ }^{3}$ Program Studi Pendikan Teknik Informatika dan Komputer Universitas Sebelas Maret \\ ${ }^{4}$ Program Studi Pendidikan Kimia Universitas Sebelas Maret
}

hsd@staff.uns.ac.id,dww_ok@staff.uns.ac.id, endarsw@staff.uns.ac.id, mariaulfa@staff.uns.ac.id

\begin{abstract}
Abstrak
Covid 19 sangat berdampak luas pada berbagai sektor, diantaranya adalah sektor pendidikan. Guru dituntut untuk memastikan proses belajar mengajar berjalan dengan baik, walaupun murid berada pada rumah masingmasing. Salah satu metode yang digunakan Guru adalah Pembelajaran Jarak Jauh (PJJ) lewat media online. Kondisi ini menimbulkan permasalahan yaitu PJJ belum efektif dan maksimal jika di implementasikan pada sekolah yang infrastukturnya belum memadai. Permasalahan tersebut juga di alami oleh para guru di SMPN 2 Surakarta. Berdasarkan permasalahan tersebut tim pengabdi memberikan solusi yaitu implementasi Google suite for education (GSE) dengan memanfaatkan akun belajar.id yang telah diluncurkan oleh Kemendikbud RI. GSE adalah paket layanan Google berbasis cloud yang dapat digunakan untuk melakukan manajemen institusi berbasis email Gmail yang sekaligus dapat di akses dengan aplikasi mobile. GSE memiliki fasilitas online learning management system yaitu google classroom. Penyelesaian masalah dilakukan melalui dukungan teknologi dan dukungan manajemen. Dukungan teknologi yang berikan melalui implementasi dan pendampingan pemanfaatan teknologi GSE melalui akun belajar.id yang akan digunakan para guru dalam proses belajar mengajar. Dukungan dari sisi manajemen berupa pengetahuan pada para guru dan murid terkait dengan aktifasi email dan pengetahuan tentang aplikasi yang dimiliki oleh GSE seperti : Google Form, Google Meet Google Docs, Google Sheet, dan Google Drive untuk menunjang proses belajar mengajar secara online/daring.
\end{abstract}

Kata Kunci : Belajar Daring, Belajarid, Gogle Suite Education

\section{PENDAHULUAN}

Organisasi Kesehatan Dunia (WHO) pada tanggal 11 Maret 2020, menyatakan bahwa Covid19 sebagai pandemi global, yang melanda seluruh dunia (Cucinotta \& Vanelli, 2020). Sejak itu, pemerintah Indonesia menetapkan Covid-19 sebagai penyakit dengan faktor risiko yang menyebabkan darurat kesehatan masyarakat, sehingga PSBB (Pembatasan Sosial Berskala Besar) harus dilaksanakan. PSBB yang diterapkan oleh pemerintah membatasi semua kegiatan sosial karena harus menjaga jarak tertentu untuk memutus mata rantai penularan virus Covid-19.

Covid 19 sangat berdampak luas pada berbagai sektor, diantaranya adalah sektor Pendidikan (Gonzalez et al., 2020). Hal tersebut mendorong Menteri Pendidikan dan Kebudayaan mengeluarkan Surat Edaran nomor 3 Tahun 2020 tentang Pencegahan Corona Virus Disease (Covid 19). Berdasarkan data UNICEF, setidaknya 1,5 milyar anak usia sekolah terdampak Covid 19 di 188 negara. Dari data tersebut terdapat 463 juta siswa yang tidak dapat mengakses pembelajaran jarak jauh / daring. Di Indonesia sendiri ada 45 juta anak 
sekolah yang telah didukung melalui pembelajaran jarak jauh baik online maupun offline selama COVID-19. (Unicef, 2020). Selain murid yang terdampak covid 19, para guru juga merasakan dampak tersebut.

Guru dituntut untuk memastikan proses belajar mengajar berjalan dengan baik, walaupun murid berada pada rumah masing-masing. Peran guru dalam implementasi kurikulum 2013 adalah sebagai fasilitator yang membantu murid dalam memecahkan masalah pembelajaran yang dialaminya (Kemedikbud, 2013). Guru dapat mengarahkan siswa agar bisa mendapatkan pengalaman secara langsung dalam pembelajaran digital berbasis teknologi informasi. Saat ini teknologi informasi yang sering digunakan untuk mendukung proses belajar mengajar adalah pembelajaran berbasis online (e-learning). Salah satu metode yang digunakan guru adalah Pembelajaran Jarak Jauh (PJJ) melalui media online seperti Google Meet, WhatsApp, Google Form, dan lain-lain. Kondisi ini menimbulkan permasalahan yaitu PJJ belum efektif dan maksimal jika di implementasikan pada sekolah yang infrastukturnya belum memadai. Hal ini diakibatkan PJJ berbasis teknologi membutuhkan pendekatan yang berbeda dalam hal perencanaan, pelaksanaan dan evaluasinya.

Permasalahan-permasalahan terkait dengan Pembelajaran Jarak Jauh juga di alami oleh para guru dan murid di SMP Negeri 2 Surakarta. Berdasarkan data dari Data Pokok Pendidikan (Dapodik) Kemendikbud, SMP Negeri 2 Surakarta saat ini mempunyai 756 peserta didik dengan sebaran 374 siswa laki-laki dan 382 siswa perempuan. SMP Negeri 2 Surakarta saat ini mempunyai 50 guru dengan guru berjenis kelamin laki-laki 17 orang dan guru berjenis kelamin perempuan sejumlah 28 orang. Untuk sarana dan prasarana saat ini SMP Negeri 2 Surakarta mempunyai 29 ruang kelas, 5 ruang laboratorium dan 1 ruang perpustakaan (Kemendikbud, 2021). Peta lokasi SMP Negeri 2 Surakarta ditampilkan pada gambar 1.

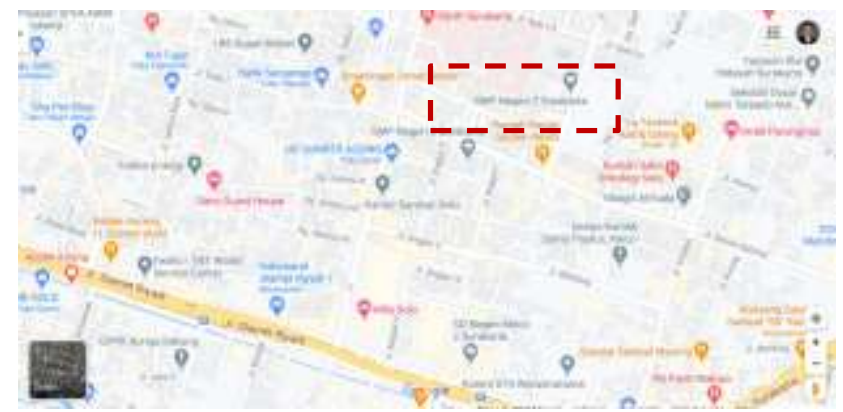

Gambar 1. Peta lokasi kelurahan SMP Negeri 2 Surakarta (sumber : Google map)

WHO telah mengubah terminologi pembatasan sosial (social distancing) dengan menjaga jarak fisik (physical distancing). (Pratomo, 2020). Kebijakan physical distancing yang dijadikan dasar dalam pelaksanaan belajar dari rumah, dengan menggunakan teknologi informasi yang berlaku secara mendadak, tidak jarang membuat guru dan murid kaget termasuk orang tua. Pembelajaran menggunakan teknologi informasi dan telekomunikasi sebenarnya sudah dilakukan dalam beberapa tahun terakhir pada sistem pendidikan di negara Indonesia. Namun, pembelajaran daring yang dilaksanakan sebagai akibat dari pandemi Covid-19, membuat kaget hampir di seluruh lini kehidupan.

Sebagai salah satu entitas pada lembaga pendidikan, Guru harus bisa membuat keputusan yang cepat dalam melaksanakan surat edaran Mendikbud yang mengharuskan sekolah untuk melakukan pembelajaran dari rumah. Guru harus mampu mengubah sistem pembelajaran, silabi dan proses belajar secara cepat. Kendala-kendala tersebut menjadikan catatan yang penting pada dunia pendidikan kita yang harus melaksanakan pembelajaran daring secara cepat. Padahal, secara teknis dilapangan belum semuanya siap.

Selama ini dibeberapa sekolah pembelajaran dengan mekanisme online hanya sebagai konsep besar, belum di implementasikan sebagai paradigma pembelajaran. Pembelajaran online/daring bukanlah metode yang digunakan untuk mengubah belajar tatap muka (luring) dengan teknologi informasi, bukan pula untuk memberikan siswa dengan tugas yang banyak setiap hari. Pembelajaran online seharusnya mendorong para siswa menjadi lebih

Teknologi Informasi dan Komunikasi 
kreatif dengan mengakses sebanyak-banyaknya sumber pengetahuan, mengasah wawasan siswa dan akhirnya akan membentuk murid menjadi pembelajar sepanjang hidup. (Suharwoto, 2020). Permasalahan - permasalahan terkait dengan pembelajaran online/daring juga di alami oleh para guru dan murid SMP Negeri 2 Surakarta.

Berdasarkan hasil diskusi awal yang dilakukan oleh Tim PKM UNS dengan Kepala Sekolah dan beberapa guru di SMP Negeri 2 Surakarta pada tanggal 15 Oktober 2020 didapatkan informasi bahwa para guru mengalami kesulitan dalam proses pembejalaran daring. Uraian permasalahan para Guru dan Murid di SMP Negeri 2 Surakarta, difokuskan dengan menggunakan diagram fishbone, agar teridentifikasi akar masalahnya. Hal ini yang akan menjadi dasar dalam merumuskan upayaupaya penyelesaian masalah. Diagram fishbone permasalahan dan akarnya ditampilkan pada Gambar 2.

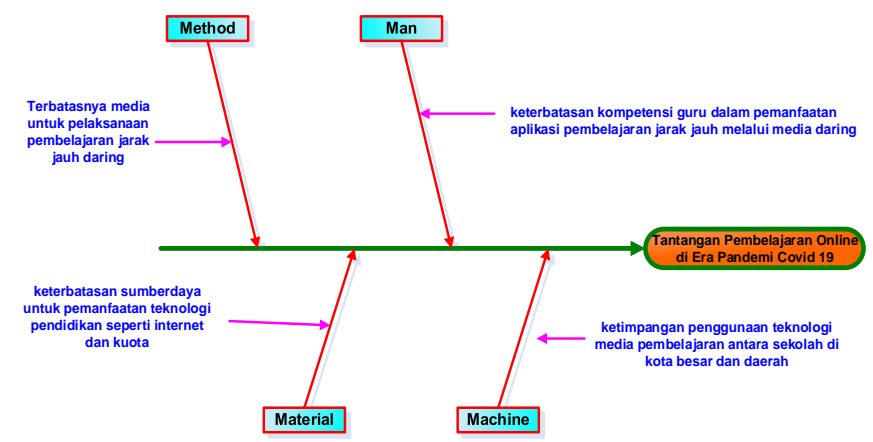

Gambar 2. Diagram Fishbone Permasalahan

Permasalahan yang dialami para guru di SMP Negeri 2 Surakarta adalah terkait dengan keterbatasan kompetensi guru dalam pemanfaatan aplikasi pembelajaran daring. Dari hasil diskusi yang dilakukan, beberapa guru menyampaikan bahwa mereka kesulitan dalam melakukan adopsi teknologi pembejaran karena faktor usia. Selain itu keterbatasan sumber daya untuk pemanfaatan teknologi Pendidikan seperti internet dan kuota juga menjadi kendala dalam proses pembelajaran jarak jauh yang dilakukan di SMP Negeri 2 Surakarta.

Permasalahan lainnya adalah terkait dengan media untuk pelaksanaan pembelajaran daring. Dari hasil diskusi yang dilakukan dengan pihak sekolah menyatakan bahwa SMP Negeri 2 Surakarta belum mempunyai teknologi media pembelajaran daring seperti e-learning yang bisa digunakan untuk mendukung guru dalam proses pembelajaran jarak jauh. Hal tersebut dikarenakan karena adanya ketimpangan teknologi yang dimilik antara sekolah besar dan sekolah di daerah.

Berdasarkan permasalahan yang telah diuraikan, maka perlu dilakukan upaya dan pencarian solusi, untuk mendukung para Guru dan Murid di SMP Negeri 2 Surakarta dalam upaya penyelesaian masalah terkait keterbatasan pembelajaran jarak jauh. Berdasarkan hasil diskusi yang telah dilakukan oleh Tim Research Group Data Information Knowlegde and Engineering (DIKE) UNS dengan para guru di SMP Negeri 2 Surakarta, secara umum upaya penyelesaian masalah dapat dilakukan melalui 2 pendekatan, yaitu pendekatan teknologi dan pendekatan manajemen.

Upaya pendekatan teknologi dilakukan dengan implementasi teknologi tepat guna yaitu implementasi dan pendampingan teknologi google suite for education yang akan digunakan para guru dalam prores belajar mengajar serta migrasi email sekolah ke layanan google for education (GSE). Kementerian Pendidikan, Kebudayaan, Riset, dan Teknologi Republik Indonesia melalui Pusat Data dan Teknologi Informasi (Pusdatin) telah meluncurkan Akun Pembelajaran dengan domain belajar.id. Akun tersebut dapat dipergunakan oleh siswa, guru, dan tenaga kependidikan untuk mengakses layanan pembelajaran berbasis digital. Akun belajar.id adalah akun Google Suite for Education yang mempunyai kelebihan, diantaranya: Penyimpanan file berbasis cloud computing Google Drive, google meet, google classroom dan lain sebagainya.

Selain penerapan teknologi tepat guna, para guru di SMP Negeri 2 surakarta juga memerlukan dukungan dari segi manajemen. Langkah yang dilakukan oleh Tim RG DIKE UNS adalah memberikan pengetahuan kepada guru terkait cara aktifasi email dengan domain sekolah yang di kelola oleh google dan melakukan sosialisasi dengan memberikan pengetahuan tentang aplikasi-aplikasi yang dimiliki oleh google suite for education.

Teknologi Informasi dan Komunikasi 61 


\section{METODE}

Penyelesaian masalah bagi para guru SMP Negeri 2 Surakarta dilakukan melalui dukungan teknologi dan dukungan manajemen. Upaya tersebut dilakukan secara aktif mengikutsertakan dan memberdayakan para guru SMP Negeri 2 Surakarta, atau yang disebut dengan istilah Participatory Rural Appraisal (PRA). Berikut akan diuraikan metode dalam pelaksanaan kegiatan PKM yang akan di lakukan oleh Tim PKM UNS dalam menyelesaikan permasalahan mitra.

\section{Metode Pelaksanaan Kegiatan}

Secara spesifik, metode pelaksanaan kegiatan yang akan digunakan untuk menyelesaikan permasalahan bagi para guru SMP Negeri 2 Surakarta meliputi :

\subsection{Metode Pelaksanaan Kegiatan Terkait Permasalahan Teknologi}

Secara rinci, terdapat dua permasalahan yang dikaji oleh Tim PKM UNS dari sisi teknologi, yaitu terkait implementasi dan pendampingan teknologi google suite for education yang akan digunakan para guru dalam proses belajar mengajar di SMP Negeri 2 Surakarta. Selain itu Tim PKM UNS juga akan membantu untuk proses migrasi email sekolah ke layanan Google suite for education melalui akun belajar.id.

\subsection{Metode Pelaksanaan Kegiatan Terkait Permasalahan Manajemen}

Implementasi teknologi di masyarakat, harus sebaiknya juga harus diikuti dengan dukungan manajemen (pengelolaan) teknologi tersebut. Terkait permasalahan manajemen ini, solusi yang diberikan adalah : Memberikan pengetahuan pada para guru dan murid terkait dengan aktifasi email dengan domain sekolah yang baru yang yang telah degenerate sebelumnya. Tim PKM UNS juga akan melakukan sosialisasi dengan memberikan pengetahuan tentang aplikasi yang dimiliki oleh Google suite for education seperti : Google Form, Google Meet Google Docs, Google Sheet, dan Google Drive. Secara umum, metode dan tahapan dalam penyelesaian permasalahan mitra digambarkan pada Gambar 3.

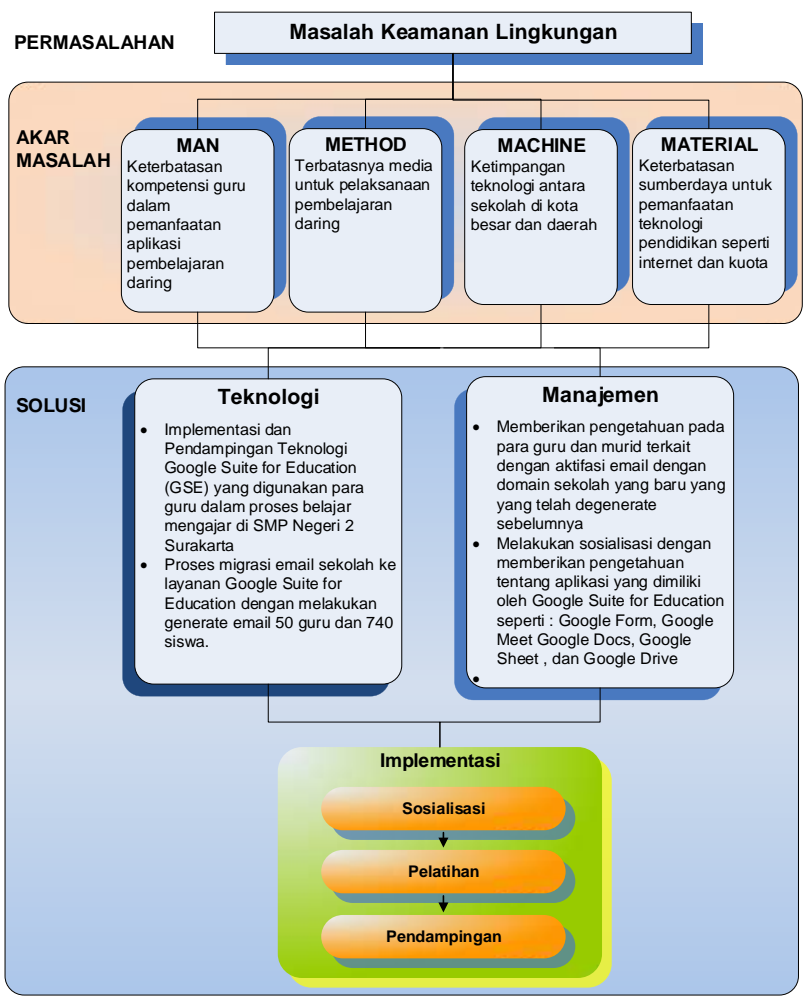

Gambar 3. Metode Penyelesaian Permasalahan

\section{Partisipasi Mitra}

Kegiatan PKM ini melibatkan para guru SMP Negeri 2 Surakarta. Pendekatan yang dipergunakan dalam kegiatan ini adalah Participatory Rural Appraisal (PRA), para Guru akan dilibatkan secara langsung dalam tahap kegiatan pengabdian. Keterlibatan warga pada setiap tahap kegiatan diuraikan sebagai berikut :

1. Guru SMP Negeri 2 Surakarta terlibat dalam diskusi brainstorming perumusan permasalahan dan terlibat dalam diskusi bagiamana cara melakukan pembelajaran online di era pandemi Covid 19.

2. Pada tahap implementasi, Guru SMP Negeri 2 Surakarta terlibat dalam pemberian masukan (feedback) berkaitan dengan proses migrasi email sekolah ke layanan google suite for education melalui akun belajar.id.

3. Pada kegiatan penyusunan modul penggunaan aplikasi google suite for education, para guru SMP Negeri 2 Surakarta terlibat untuk

Teknologi Informasi dan Komunikasi 62 
memberikan masukan (feedback) terkait dengan konten modul. Hal ini dilakukan mengingat modul ini nantinya akan dipergunakan sebagai panduan para guru, agar dapat menggunakan aplikasi yang dimiliki oleh google suite for education secara mandiri dan berkelanjutan.

4. Para guru SMP Negeri 2 Surakarta terlibat menjadi koordinator peserta sosialisasi dan pelatihan aplikasi teknologi tepat guna yang akan di implementasikan.

Guru SMP Negeri 2 Surakarta berperan dan berpartisipasi pada kegiatan ini dengan memberikan fasilitas tempat, sumber daya manusia. Selain itu, para guru diharapkan dapat berperan menjadi agen untuk dapat menyebarkan ilmu pengetahuan dan teknologi (iptek) yang telah diberikan oleh tim PKM UNS kepada guru lainnya di luar SMP Negeri 2 Surakarta. Tabel 1 menampilkan wujud partisipasi dan keterlibatan warga pada kegiatan PKM kali ini.

Tabel 1. Bentuk Partisipasi dan Dukungan Mitra kepada Tim PKM UNS

\begin{tabular}{|c|c|c|}
\hline NO & PARTISIPASI & KETERANGAN \\
\hline 1. & $\begin{array}{l}\text { Penyediaan } \\
\text { tempat }\end{array}$ & $\begin{array}{ll}\text { - } & \text { Ruangan untuk } \\
\text { diskusi tim PKM di } \\
\text { ruang rapat } \\
\text { - } & \text { Penyediaan tempat } \\
& \text { sosialisasi \& } \\
& \text { pelatihan. }\end{array}$ \\
\hline 2. & $\begin{array}{l}\text { Sumber Daya } \\
\text { Manusia }\end{array}$ & $\begin{array}{ll}\text { - } & \text { Obyek pelaku } \\
& \text { aplikasi teknologi } \\
\text { - } & \text { Peserta sosialisasi } \\
\text { - } & \text { Peserta pelatihan } \\
\text { - } & \text { Peserta } \\
& \text { pendampingan }\end{array}$ \\
\hline
\end{tabular}

\section{HASIL DAN PEMBAHASAN}

\section{Hasil Pengabdian dan Pembahasan}

Kemendikbudristek melalui Pusdatin meluncurkan akun pembelajaran dengan domain belajar.id. Akun tersebut dapat dipergunakan oleh guru, siswa, dan tenaga kependidikan untuk mengakses layanan pembelajaran berbasis digital. Akun belajar.id adalah akun GSE yang mempunyai kelebihan yaitu : Penyimpanan file berbasis cloud computing Google Drive. Fitur-fitur yang lainnya adalah Google Classroom, Google Calender, Google Meet, Google Form dan lain-lain.

\subsection{Aktiviasi Akun Pembelajaran Belajar.id}

Akun Pembelajaran adalah akun yang memuat user ID password yang diterbitkan oleh Kemendikbudristek RI. Akun ini dapat digunakan oleh guru, murid, dan tenaga kependidikan sebagai akun yang digunakan untuk mengakses aplikasi pembelajaran berbasis elektronik/digital. Akun pembelajaran didapatkan dari sistem dapodik yang dapat di download oleh operator satuan pendidikan masing-masing sekolah. Akun yang di unduh dalam bentuk file .csv yang berisi username dan password.

Setelah file .csv yang berisi akun pembelajaran di unduk dari aplikasi dapodik, tim pengabdian masyarakat RG DIKE membantuk untuk mendistribusikan akun tersebut kepada guru dan siswa SMP Negeri 2 Surakarta. Untuk medistribusikan akun tersebut kami membagikan google form yang disebarkan via whatsapp group masing-masing kelas melalui wali kelas untuk meminta data nomor telepon siswa. Contoh google form yang kami sebarkan kepada siswa dapat dilihat pada gambar 4 .

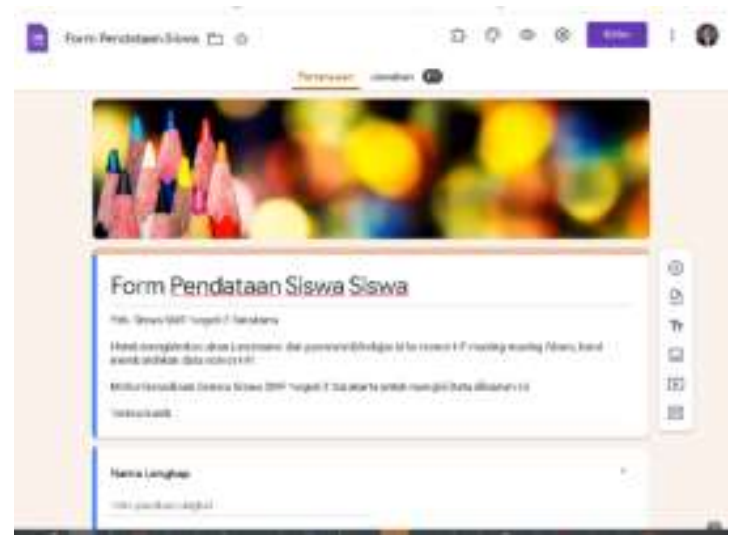

Gambar. 4 Formulir Pendataan Siswa dan Guru melalui google form

Dari formulir pendataan siswa dan guru di SMP Negeri 2 Surakarta didapatkan 453 data nomor 
telepon. Langkah selanjutnya tim pengabdian masyarakat RG DIKE UNS melakukan broadcast melalui sistem whatsapp blast kepada siswa dan guru yang telah mengisi formulir tersebut. Contoh pengiriman whatsapp blast kepada siswa dan guru dapat dilihat pada gambar 5

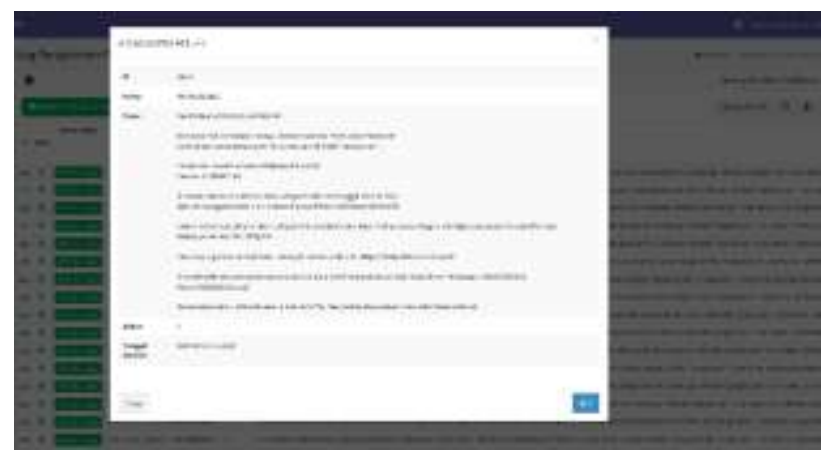

Gambar 5. Contoh whatsapp blast untuk mengirim akun belajar.id kepada siswa \& guru

\subsection{Sosialisasi dan Pendampingan Kepada Guru dan Siswa}

Langkah selajutnya setelah mendistribusikan akun belajar.id via broadcast melaluji whatsapp blast, tim RG DIKE UNS melakuan sosialisasi dan pendampingan kepada guru dan siswa. Sosilalisasi dan pendampingan dilakukan secara luring dan daring di SMP Negeri 2 Surakarta dengan mengundang guru dan perwakilan siswa masingmasing 5 siswa per kelas. Jumlah peserta yang hadir dalam acara tersebut sejumlah 73 peserta. Aktivitas kegiatan sosialisasi dan pendampingan tersebut dapat dilihat pada gambar 6 .

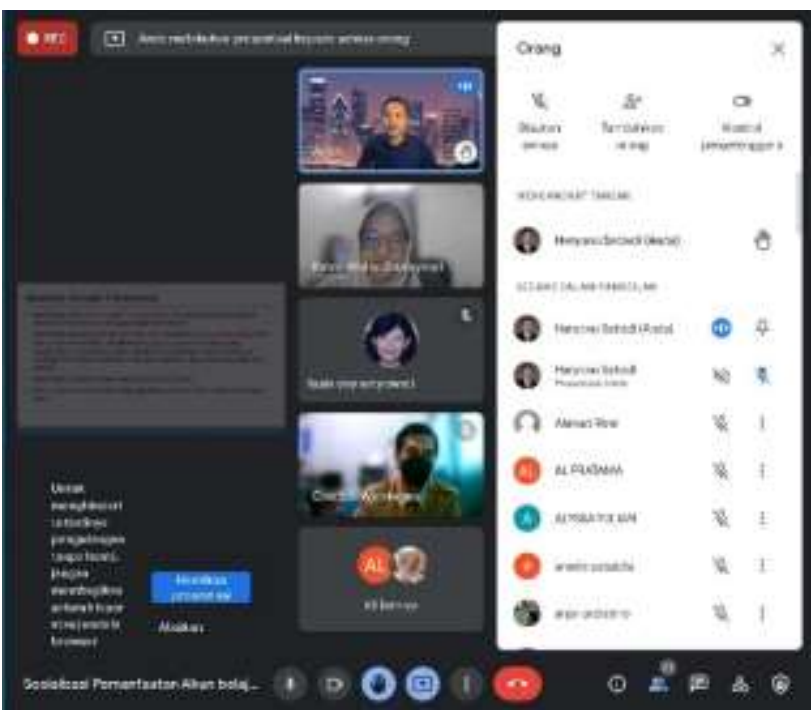

Gambar. 6. Acara Sosialisasi dan Pendampingan Pemanfaatan akun belajar.id

Materi yang disampaikan pada acara sosialisasi dan pendampingan adalah terkait dengan tatacara aktivasi akun pembelajaran, pemanfatan google calender untuk pengelolaan agenda kegiatan, pemafaatan google docs, google spreadsheet dan google slide untuk pendukung kegiatan belajar mengajar. Selain itu tim pengabdian masyarakat RG DIKE UNS juga memberikan pemaparan terkait dengan pemanfaatan google meet dan google class room untuk penunjang kegiatan belajar mengajar secara daring. Contoh materi sosialisasi yang diberikan kepada guru dan siswa dapat dilihat pada gambar 7.

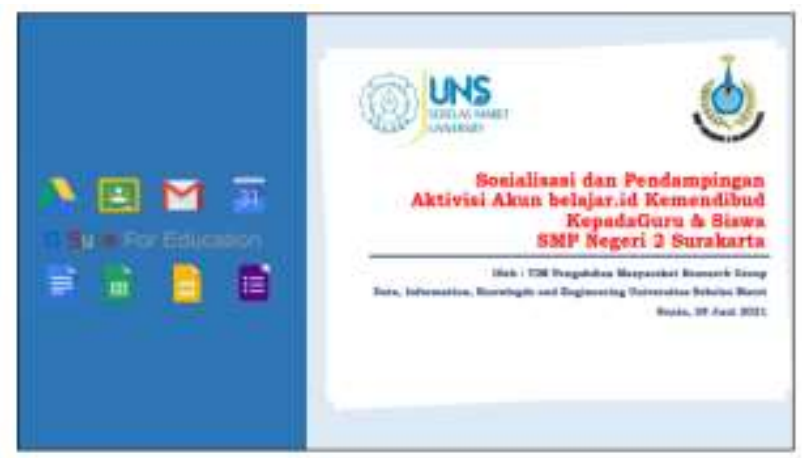

Gambar 7. Contoh Materi yang diberikan pada acara sosialisasi dan pendampingan 


\section{KESIMPULAN}

Sesuai dengan rencana kegiatan dan prosedur kerja yang sudah dibuat oleh Tim PKM Research Group DIKE UNS, kegiatan ini di akhiri dengan kegiatan pendampingan sekaligus melakukan evaluasi kegiatan. Kegiatan pendampingan bertujuan untuk memastikan para guru dan murid dapat menggunakan teknologi google suite for education (GSE) melalui akun belajar.id yang digunakan para guru dalam proses belajar mengajar di SMP Negeri 2 Surakarta. Kegiatan pendampingan bertujuan untuk memastikan guru dan siswa dapat mengunakan akun pembelajaran untuk proses meningkatkan efektivitas kegiatan belajar mengajar.

Tim Pengabdian masyarakat RG DIKE UNS selain memberikan dukungan berupa teknologi GSE juga memberikan sosialisasi dan pendampingan tentang aplikasi yang dimiliki oleh Google suite for education yang bisa diakses melalui akun pembelajaran seperti : Google Form, Google Meet Google Docs, Google Sheet, dan Google Drive kepada guru dan murid. Pelatihan ini bertujuan agar para guru dan murid bisa memanfaatan teknologi google for education untuk pembelajaran daring secara mandiri. Diharapkan para guru di SMP Negeri 2 Surakarta dapat menjadi agen untuk menyebarkan ilmu pengetahuan dan teknologi (Iptek) yang telah diberikan oleh tim PKM UNS kepada Guru-Guru lain di wilayah surakarta dan sekitarnya. Hal tersebut dapat menjadikan keberlanjutan dari Pogram Kemitraan Masyarakat yang di isiansi oleh tim PKM RG DIKE UNS.

\section{REFERENSI}

Cucinotta, D., \& Vanelli, M. (2020). WHO declares COVID-19 a pandemic. Acta Biomedica, 91(1), 157-160. https://doi.org/10.23750/abm.v91i1.9397

Gonzalez, T., De la Rubia, M. A., Hincz, K. P.,
Comas-Lopez, M., Subirats, L., Fort, S., \& Sacha, G. M. (2020). Influence of COVID-19 confinement on students' performance in higher education. PLOS ONE, 15(10 October), $1-23$.

https://doi.org/10.1371/journal.pone.0239490

Kemedikbud. (2013). Kompetensi Dasar Kurikulum 2013, (Mi).

Kemendikbud, D. P. P. (2021). Data PTK dan PD SMPN 2 Surakarta. Retrieved January 10, 2020, from https://dapo.kemdikbud.go.id/sekolah/F1E5E6 3DF85490C934DD

Pratomo, H. (2020). From social distancing to physical distancing: A challenge forevaluating public health intervention against covid-19. Kesmas, 15(2), 60-63. https://doi.org/10.21109/KESMAS.V15I2.401 0

Suharwoto, G. (2020). Pembelajaran Online di Tengah Pandemi Covid-19, Tantangan yang Mendewasakan. Retrieved January 5, 2020, from

https://pusdatin.kemdikbud.go.id/pembelajara n-online-di-tengah-pandemi-covid-19-

tantangan-yang-mendewasakan/

Unicef. (2020). COVID-19: Laporan baru UNICEF mengungkap setidaknya sepertiga anak sekolah di seluruh dunia tidak dapat mengakses pembelajaran jarak jauh selama sekolah ditutup. Retrieved January 10, 2020, from https://www.unicef.org/indonesia/id/pressreleases/covid-19-laporan-baru-unicefmengungkap-setidaknya-sepertiga-anaksekolah-di-seluruh

Teknologi Informasi dan Komunikasi 65 